\title{
AKTIFITAS UV PROTEKTIF EKSTRAK BUAH JAMBLANG
}

\author{
UV Protective Activity of Jamblang Extracts
}

\author{
Ida Adhayanti ${ }^{1}$, Nurisyah ${ }^{2}$, Tajuddin Abdullah ${ }^{3}$ \\ ${ }^{1,2,3}$ Jurusan Farmasi Poltekkes Kemenkes Makassar
}

\author{
Koresponden : \\ Ida Adhayanti \\ Email : ida.adhayanti@ poltekkes-mks.ac.id \\ HP : 082194998844 \\ DOI: https://doi.org/10.32382/mf.v15i1.858
}

\begin{abstract}
ABSTRAK
Buah Jamblang mengandung banyak komponen polifenol yang dapat berfungsi sebagai penangkal radikal bebas. Radikal bebas yang tidak dapat terhindarkan sehari-hari adalah radiasi sinar UV. Tujuan dari penelitian ini adalah untuk menentukan aktivitas UV protektif dari ekstrak buah jamblang. Ekstrak yang diuji meliputi ekstrak etil asetat, ekstrak etanol dan ekstrak air yang diperoleh melalui metode maserasi. Penentuan Aktivitas UV protektif dilakukan melalui penentuan Nilai SPF dengan menggunakan persamaan yang dikembangkan oleh Mansur. Berdasarkan hasil penelitian diperoleh data ekstrak etil asetat dengan nilai SPF sebesar 17,56 (kategori proteksi ultra), kemudian ekstrak air dengan nilai SPF sebesar 7,49 (kategori proteksi ekstra), dan ekstrak etanol dengan nilai SPF sebesar 3,31 (kategori proteksi minimal). Ekstrak etil asetat memiliki aktivitas yang paling baik dibandingkan dengan ekstrak etanol dan air.
\end{abstract}

Kata Kunci : UV, Jamblang, Tabir Surya

\section{PENDAHULUAN}

Buah Jamblang (Syzygium cumini) merupakan familia dari Myrtaceae, merupakan sejenis pohon buah yang terdistribusi di seluruh benua India, Asia Tenggara dan Afrika Timur. Di Indonesia, tanaman ini dikenal dengan berbagai nama diantaranya rappo-rappo jawa (Selayar), Coppeng (Makassar/Bugis), jambee kleng (Aceh), jambu koliong (Riau), jambulan (Flores), duwe (Bima), dll. Buah Jamblang ini banyak di gunakan di berbagai negara, termasuk Indonesia, untuk pengobatan terhadap berbagai penyakit termasuk diabetes. Kulit tanaman bersifat karminatif sehingga baik untuk pencernaan, antihiperglikemia, anthelmintic dan antibakteri. Buah dan Biji digunakan untuk mengobati diabetes, faringitis, spleenopathy dan infeksi kurap. Daun memiliki sifat antibakteri dan digunakan untuk memperkuat gigi dan gusi. Daunnya telah banyak digunakan untuk mengobati diabetes, sembelit, keputihan, demam, gastropati dan untuk menghambat keluarnya darah dalam tinja (Srivasta dan Chandra 2013).
Berbagai manfaat kesehatan yang dimiliki oleh tanaman ini diduga karena kandungan komponen-komponen fenoliknya yang tinggi. Asam fenolik, flavonoid dan tannin merupakan komponen fenol terbesar yang tersebar pada bagian-bagian tumbuhan dari buah jamblang. Komponen ini merupakan penangkal radikal bebas yang sangat baik. Buah jamblang kaya akan antosianin yang memiliki daya antioksidan yang tinggi. Selain antosianin, buah jamblang juga mengandung berbagai metabolit sekunder seperti asam ellagik, asam gallat, kuersetin, myrisetin, kaempferol, tannin terkondensasi dan tannin terhidrolisis dalam konsentrasi yang berbeda-beda (Singh, dkk 2018).

Komponen fenolik memiliki kemampuan untuk menangkal radikal bebas. Salah satu sumber radikal bebas adalah radiasi sinar ultarviolet dari matahari. Indonesia merupakan negara yang kaya akan sinar matahari, sehingga pemakaian tabir surya sangat dianjurkan untuk mencegah kerusakan kulit akibat radiasi UV. Komponen-komponen fenolik ini mampu menangkal radikal bebas yang disebabkan 
oleh radiasi sinar UV sehingga dapat digunakan sebagai tabir surya. Penelitian mengenai aktivitas farmakologis dari buah jamblang telah banyak diteliti, demikian pula dengan aktivitas antioksidannya. Dalam hal ini peneliti tertarik untuk mengkaji aktivitas tabir surya (UV protektif) dari beberapa macam ekstrak buah Jamblang. Tujuan dari penelitian ini adalah untuk menentukan aktivitas UV protektif dari beberapa macam ekstrak buah jamblang.

\section{METODE}

\section{Desain, Tempat dan Waktu}

Penelitian ini merupakan penelitian observasi laboratorium yang dilaksanakan di Laboratorium Kimia, Jurusan Farmasi Poltekkes Kemenkes Makassar pada tahun 2018.

\section{Bahan dan Alat}

Bahan-bahan yang digunakan dalam penelitian ini adalah buah jamblang, pelarut organik berupa etanol, etil asetat dan air suling, Alat-alat yang digunakan dalam penelitian ini adalah seperangkat alat maserasi, seperangkat alat-alat kaca seperti erlenmeyer, gelas ukur, gelas kimia, rotary evaporator, Spektrofotometer UV-Vis, Freeze Drier.

\section{Langkah-langkah Penelitian}

1. Penyiapan Sampel

Buah Jamblang dibersihkan dari kotoran yang menempel dengan air mengalir sampai benar-benar bersih. Lalu buah yang sudah bersih kemudian dikurangi kadar airnya dengan cara dipotong tipis. Selanjutnya dianginanginkan dalam suhu kamar tanpa terkena sinar matahari langsung sampai benar-benar kering lalu dilakukan proses ekstraksi selanjutnya.

2. Pembuatan Ekstrak

Simplisia buah jamblang diekstraksi dengan metode maserasi menggunakan alat orbital shaker. Simplisia Buah Jamblang ditimbang sebanyak 100 gram, lalu di masukkan ke dalam erlenmeyer $250 \mathrm{ml}$. Kemudian ditambahkan air hingga terendam sempurna, lalu erlenmeyer ditutup dengan kapas yang terbungkus alumunium foil. Setelah itu di kocok menggunakan shaker selama 4 jam.
Kemudian didiamkan dan di saring untuk mengambil filtratnya.Filtrat buah jamblang dimasukkan ke dalam freezer hingga beku, kemudian di masukkan ke dalam freeze dryer untuk mendapatkan ekstrak kering. Kemudian berat ekstrak air yang kental ditimbang untuk diketahui beratnya. Untuk membuat ekstrak etil asetat, maka sebanyak 250 gram simplisia kering ditimbang, kemudian diekstrasi dengan pelarut etil asetat dengan langkah-langkah yang sama dengan pembuatan ekstrak air. Pengentalan ekstrak dilakukan dengan menggunakan rotary evaporator. Untuk membuat ekstrak etanol, maka residu dari ekstraksi dengan etil asetat dikeringkan terlebih dahulu baru kemudian diekstraksi dengan menggunakan pelarut etanol. Langkahlangkah selanjutnya sama dengan pembuatan ekstrak etil asetat.

3. Pembuatan Larutan Sampel

Ditimbang dengan seksama masingmasing ekstrak buah jamblang sebanyak $500 \quad \mathrm{mg}$ kemudian dimasukkan ke dalam labu ukur $50 \mathrm{ml}$, dan diencerkan dengan etanol, selanjutnya dicukupkan hingga tanda (10.000 ppm). Kemudian dari larutan tersebut dipipet sebanyak $1 \mathrm{ml}$, dimasukkan ke dalam labu ukur $10 \mathrm{ml}$, kemudian diencerkan dengan etanol hingga tanda sehingga diperoleh konsentrasi masing-masing ekstrak sebesar $1 \mathrm{mg} / \mathrm{ml}$.

4. Pengukuran Serapan Sampel

Sampel diukur serapannya pada panjang gelombang $290 \mathrm{~nm}$ sampai 320 $\mathrm{nm}$ dengan interval $5 \mathrm{~nm}$ yaitu panjang gelombang sinar UV dan dihitung nilai log SPF yang merupakan nilai rata-rata dari serapan dan kemudian ditentukan nilai SPF serta jenis proteksi tabir dari beberapa ekstrak Buah Jamblang

\section{Pengolahan dan Analisis Data}

Data serapan yang diperoleh dari hasil pengukuran kemudian diolah untuk memperoleh nilai Sun Protecting Factor (SPF) dengan menggunakan rumus (Mansur, dkk, 1986):

$$
\mathrm{SPF}=\mathrm{CF} \times \sum^{290-320} \mathrm{EE}(\lambda) \times I(\lambda) \times
$$

$$
\operatorname{Abs}(\lambda)
$$


Dimana , CF = 10 (faktor koreksi), $\mathrm{EE}(\lambda)=$ Erythematogenic effect of radiation of wavelength $\lambda$, I $(\lambda)=$ Intensity of solar radiation at a wavelength and $\operatorname{Abs}(\lambda)=$ serapan pada $\lambda$. Nilai $\operatorname{EE}(\lambda) \times \mathrm{I}(\lambda)$ adalah konstan sebagai mana tersaji pada Tabel 1 (Sayre et al, 1979).

\section{HASIL}

Aktivitas UV protektif ekstrak buah jamblang dinyatakan dalam nilai SPF yang diperoleh dari hasil analisis data dengan menggunakan rumus yang dikembangkan oleh Mansur dkk (1986). Data tersebut dapat dilihat pada tabel 2. Berdasarkan data tersebut, aktivitas UV Protektif yang paling baik ditunjukkan oleh ekstrak etil asetat dengan nilai SPF 17,56 dimana aktivitas UV protektif ini dikategorikan dalam kategori ultra, kemudian ekstrak air dengan nilai SPF 7,49 yang masuk dalam kategori ekstra dan ekstrak etanol dengan nilai SPF 3,31 yang masuk dalam kategori perlindungan minimal.

\section{PEMBAHASAN}

Efektifitas dari suatu sediaan tabir surya dapat ditunjukkan salah satunya adalah dengan nilai sun protection factor (SPF), yang didefinisikan sebagai jumlah energi UV yang dibutuhkan untuk mencapai minimal erythema dose (MED) pada kulit yang dilindungi oleh tabir surya, dibagi dengan jumlah energi UV yang dibutuhkan untuk mencapai MED pada kulit yang tidak diberikan perlindungan. MED didefinisikan sebagai jangka waktu terendah atau dosis radiasi sinar UV yang dibutuhkan untuk menyebabkan terjadinya erythema (Pratama dan Karim 2015).

Pengukuran nilai SPF suatu sediaan tabir surya dapat dilakukan secara in vitro. Pengukuran nilai SPF secara in vitro, secara umum terbagi dalam dua tipe. Tipe pertama adalah dengan cara mengukur serapan atau transmisi radiasi UV melalui lapisan produk tabir surya pada plat kuarsa atau biomembran. Tipe yang kedua adalah dengan menentukan karakteristik serapan tabir surya yang diuji (Hairuddin.,2014).

SPF didefinisikan sebagai dosis eritema minimal pada kulit yang dilindungi oleh sediaan tabir surya dibagi dengan dosis eritema minimal pada kulit yang tidak dilindungi oleh sediaan tabir surya. SPF merupakan suatu nilai yang dapat menggambarkan tingkat efektivitas dari suatu sediaan tabir surya. Semakin tingggi nilai SPF yang diperoleh, maka semakin efektif sediaan tersebut dalam mencegah kulit menjadi terbakar dan terhindar dari kerusakan kulit lainnya (Kaur and Swanlata,2010).Tingkat kemampuan tabir surya berdasarkan nilai SPF menurut Damogalad,Edy,dan Supriati(2013) dapat dilihat pada tabel 3 .

Penentuan aktivitas UV protektif dari ekstrak buah jamblang adalah berdasarkan nilai SPFnya. Beberapa macam ekstrak yang diuji adalah ekstrak air, ekstrak etanol dan ekstrak etil asetat dari buah jamblang. Pengujian pada beberapa macam ekstrak ini bertujuan untuk menentukan ekstrak yang manakah yang memiliki aktivitas UV protektif yang pali

Metode ekstraksi yang digunakan adalah metode maserasi. Maserasi merupakan metode ekstraksi yan paling sederhana dan paling banyak digunakan karena metode ini sesuai dan baik untuk skala kecil maupun skala industri. Teknik pengerjaannya pun relatif sederhana dan mudah dilakukan, peralatan yang digunakan sangat sederhana, biaya operasionalnya relatif murah, dapat digunakan untuk mengekstraksi tanpa pemanasan.

Penentuan aktivitas UV Protektif ekstrak buah jamblang dilakukan secara In vitro dengan metode spektrofotometri. Berdasarkan penelitian terdahulu metode ini paling umum digunakan untuk pengujian aktivitas tabir surya dan juga merupakan metode yang sangat sederhana, cepat, serta bahan kimia dan sampel yang digunakan sedikit. Pengukuran dilakukan secara spektrofotometri karena panjang gelombang yang diukur berkisar 290-320 nm (UVB). Konsentrasi larutan yang dibuat adalah 1 $\mathrm{mg} / \mathrm{ml}$ untuk masing-masing ekstrak dengan menggunakan pelarut etanol sebagai larutan pengencer dan blanko kemudian dilakukan replikasi sebanyak tiga kali.

Sediaan dikatakan dapat memberikan perlindungan apabila memiliki nilai SPF 2-100. Berdasarkan data yang diperoleh, nilai SPF terbaik ditunjukkan oleh ekstrak etil asetat kemudian ekstrak air dan ekstrak etanol. Ekstrak etil asetat memiliki nilai SPF terbaik yang masuk dalam kategori proteksi ekstra. 
Aktivitas UV Protekif yang dimiliki oleh buah jamblang ini kemungkinan karena kandungan komponen fenol yang dimilikinya. Dimana komponen ini dapat mengikat radikal bebas yang disebabkan oleh radiasi UV sinar matahari. Dalam penelitian sebelumnya, ekstrak etil asetat buah memiliki daya antioksidan yang lebih baik dibandingkan ekstrak air dan ekstrak etanol (Adhayanti, 2018). Hal ini sejalan dengan hasil penelitian ini, dimana aktivitas UV protektif yan g terbaik juga ditunjukkan oleh ekstrak etil asetat.

\section{KESIMPULAN}

Berdasarkan hasil penelitian yang telah dilaksanakan maka dapat disimpulkan bahwa aktivitas UV protektif dari ekstrak buah Jamblang berdasarkan jenis ekstraknya yakni, ekstrak etil asetat memiliki nilai SPF sebesar 17,59 yang masuk dalam kategori proteksi ultra, ekstrak air memiliki nilai SPF sebesar 7,49 yang masuk dalam kategori proteksi ekstra dan ekstrak etanol yang memiliki nilai SPF sebesar 3,31 yang masuk dalam kategori minimal. Ekstrak dengan aktivitas UV protektif terbaik adalah ekstrak etil asetat.

\section{SARAN}

Berdasarkan hasil penelitian yang diperoleh, maka saran untuk penelitian selanjutnya adalah formulasi sediaan krim tabir surya dengan menggunakan ekstrak etil asetat yang memerikan proteksi ultra terhadap sinar matahari.

\section{UCAPAN TERIMA KASIH}

Ucapan terima kasih kepada pihakpihak yang banyak membantu dalam pelaksanaan penelitian ini yakni Alfrida Monica S, Santi Sinala, Eka Wardhana, Masniati Muhaimin dan Hasni Utami sehingga penelitian ini dapat terselesaikan dengan sebaik-baiknya.

\section{DAFTAR PUSTAKA}

Adhayanti I, Ahmad T, 2018, Aktivitas Antioksidan Ekstrak Buah Jamblang, Media Kesehatan.

Damogalad, Viondy dkk (2013). Formulasi Krim Tabir Surya Ekstrak Kulit Nanas (Ananas Comosus L Merr) Dan Uji In Vitro Nilai Sun Protecting Factor (SPF). Jurnal Ilmiah Farmasi UNSRAT Vo.2 No.2.

Hairuddin. (2014). Penentuan Nilai SPF Ekstrak Rumpul Laut. KTI pada Politeknik Kesehatan Kementrian Kesehatan Makassar.

Kaur, C.D.and Saraf S. (2010). Invitro Sun Protection Factor Determination of Herbal Oils Used Cosmetics. Article Pharmacognosy Research,Vol.2, No.1. hal.22-23.

Mansur,J.S.,et all. (1986). Determination of Sun Protection Factor for Spectrophoto, etry An. Bras.Dermatol. Rio de Janeiro.

Pratama,W.A,Karim,Z. (2015). Uji SPF In Vitro dan Sifat Fisik Beberapa Produk Tabir Surya yang Beredar Di Pasaran. Majalah Farmaseutik. 11,(01),275-283.

Singh B, Singh J.P, Kaur A, Singh N, 2018, Insight into the phenolic compounds present in Jambolan (Syzygium cumini) along with their healthpromoting effects, International Journal of Food Science and Technology, 53, 2431-2447

Srivastava S, Chandra D, 2013, Pharmacological potenstials of Syzygium cumini : a review, J.Sci.Food Agric, 93, 2084-2093 


\section{DAFTAR TABEL}

Tabel 1.Nilai Konstan EE x I

\begin{tabular}{cc}
\hline Panjang Gelombang & EExI $(\lambda)$ \\
\hline 290 & 0.015 \\
295 & 0.0817 \\
300 & 0.2874 \\
305 & 0.3278 \\
310 & 0.1864 \\
315 & 0.0837 \\
320 & 0.0180 \\
\hline Total & 1 \\
\hline
\end{tabular}

Tabel 2. Aktivitas UV Protektif Ekstrak Buah Jamblang dinyatakan dalam Nilai SPF

\begin{tabular}{cccc}
\hline Ekstrak & Konsentrasi Ekstrak & Nilai SPF & Kategori Proteksi \\
\hline Ekstrak Air & $1 \mathrm{mg} / \mathrm{ml}$ & 7,49 & Ekstra \\
Ekstrak Etanol & $1 \mathrm{mg} / \mathrm{ml}$ & 3,31 & Minimal \\
Ekstrak Etil Asetat & $1 \mathrm{mg} / \mathrm{ml}$ & 17,56 & Ultra \\
\hline
\end{tabular}

Tabel 3. Keefektifan sediaan tabir surya berdasarkan nilai SPF

\begin{tabular}{cc}
\hline SPF & Kategori Proteksi Tabir Surya \\
\hline $2-4$ & Minimal \\
$4-6$ & Sedang \\
$6-8$ & Ekstra \\
$8-15$ & Maksimal \\
$>15$ & Ultra \\
\hline
\end{tabular}

(Sumber: Damogalad dkk,2013:42) 